\title{
The Pricing of Trees: A Study of Hold-Ups, Holdouts, Buy-Outs ANd Sell-Offs
}

\author{
W Duncan Reekie ${ }^{1}$
}

School of Economic and Business Sciences, University of the Witwatersrand

\begin{abstract}
This paper draws on transactions cost analysis, price and auction theory, and competition authority findings in order to answer some questions on the structure and trading patterns of the South African forestry industry. Does a forestry firm linked contractually to supply an adjacent sawmill customer form part of a bilateral monopoly? For competition policy, what are the relevant markets each party sells into or buys from? Can either firm opportunistically hold-up the other in price revisions? Or, where contracts have no effective terminal date, can one party hold out against offers of contract buyout? If one party is a state agency are there rights of eminent domain? If the state agency is due to be privatised can the method of sale, for example a simultaneous ascending auction, resolve some of the dilemmas?
\end{abstract}

JEL L42, 43, 44

\section{1}

\section{Introduction}

There have been at least two investigations of South African forestry completed by the Competition authorities (the Board, 1998 and the Tribunal, 2001). Litigation between the state as forester and some sawmillers has been endemic. Government is privatising its forest interests. A common thread runs through these regulatory, litigious and restructuring activities. Formal arbitration within the framework of contract law to determine periodic price revisions has been common. The objective of the legal proceedings has been to prevent cancellation of so-called 'evergreen' contracts that have no terminal date. Complaints to the Competition authorities by industry members reflect these contractual issues, while the privatisation process requires their resolution.

Section 2 draws on the Competition Board Report to describe the nature and structure of the industry. Section 3 discusses some characteristics of the industry's long-term contracting system, in particular the provisions (if any) for buyout and revision. Section 4 shows that the Competition Tribunal, like the Board before it, gave little weight to eminent domain concerns. Price determination was the real issue. The contractual system had evolved as an alternative to vertical integration, and given that one party is the state raised issues of eminent domain. The question as to whether price determination is competitive in outcome, or strategic in intent, is evaluated in Sections 5 and 6 . The obstructiveness of some sawmillers to negotiated price revisions over the last decade can be interpreted as resistance to exploitation by a dominant firm (an explanation rejected by the Competition authorities), or it can be seen as opportunistic hold-up. Alternatively it can also be interpreted as holdout against the exercise of eminent domain. Timber buyers have been attempting to preserve established contractual rights. They wish to prolong the flow of windfall gains enjoyed from poorly written contracts drawn up in the early post-1945 decades. Section 7 expands on these arguments whilst noting that it is difficult to ascertain which 
motive is uppermost. Section 8 suggests that the intended privatisation of state forest interests gives policy makers a unique opportunity. Participants in the forestry industry, existing and potential millers, as well as outside investors, potential and existing growers could reveal, through a properly constructed simultaneous ascending auction, their true valuations of the rights to grow, process and market forestry products. The motivations underlying the revealed valuations (the ability to continue to engage in or avoid opportunistic hold-up; or the desire to holdout for unspecified compensation) would then be of little consequence. Section 9 provides a short summary of the issues at stake.

\section{2}

\section{The Competition Board investigation, 1998}

Long-term contracts were originally entered into between the state and sawmillers shortly after World War II. They were designed to provide security of supply for sawmillers and hence encourage the growth of the post-war sawmilling industry. The price structure for several decades had been unrelated to the world market price for saw logs. (Saw logs, broadly speaking, are sold to millers to manufacture lumber.) Prior to the vesting of state forests in SAFCOL in 1993 their assets were managed by the Department of Water Affairs and Forestry (DWAF). In 1969-70 DWAF concluded over 50 long-term contracts for the supply of saw $\operatorname{logs}$ to certain sawmillers. The contracts were essentially of indefinite duration, with ultimate termination being at the discretion of the sawmiller. Price revisions were provided for, usually on an annual basis. If the Minister felt that no agreement could be reached, the matter was referred to arbitration. In 1993 SAFCOL inherited 27 of these contracts, allocated among 16 customers. (Forests located in the former 'homelands' continued to be owned and managed by DWAF until 2001 when many of them were also transferred to SAFCOL.)

In its submission to the Competition Board (Report 61: paras 9 \& 10) SAFCOL claimed that its remit from government included the requirement to operate as if it were already a privatised company whose success should be measured on the basis of profit. This obligation, it was argued, implied revision of the long-term contracts and the alignment of domestic with world prices.

The Board's investigation had been prompted by complaints made by individual sawmilling companies, as well as by the South African Lumber Millers' Association (SALMA). In essence the complaints related to issues of supply security and price. SAFCOL was accused of market dominance, enabling it to enforce revised terms of sale. These included the replacement of the evergreen contracts with renewable long-term contracts that could be terminated by either party with notice; the delinking of the contracts from specific plantations; and the practise of discriminatory pricing in favour of SAFCOL's own milling subsidiaries (Report 61: paras 54, 55 and 110).

At the time of the investigation SAFCOL's share of saw log sales to mills was put at between 35-40 per cent. But the Board emphasised (para 13) that this figure ignored the fact that 'the other major suppliers of saw logs primarily supply such logs to their own downstream, "inhouse", sawmills'. Thus, the Board concluded, 'the timber produced by Sappi and Mondi can be disregarded in the delineation of the relevant (timber for lumber milling) product market. This leaves SAFCOL as the principal, or in many instances the only, supplier of soft wood saw logs to particular independent users of the product ...'(paras 99-100).

The Board found SAFCOL to be a dominant supplier of sawlogs, but found no evidence of discriminatory pricing. It confessed it was 'not in a position to prescribe or even offer meaningful advice on the appropriate duration' of the long-term contracts (para 114). But it did note that while transferring the rights and obligations of government from DWAF to SAFCOL was 'a relatively simple legal matter' the 'full extent of [the] ramifications' of the shift from a 'benign Government supplier of softwood saw logs' to a 'commercially-oriented ... SAFCOL' were 'probably not anticipated' (paras 107-8). 
The Board's conclusions (para 115) were even-handed, but essentially gave approval to SAFCOL's competitive conduct:

In the best long-term interests of the industry it is imperative for SAFCOL and the lumber millers to have a greater appreciation of each other's legitimate expectations and concerns. In particular, SAFCOL should be sensitive to the 'security of supply' concerns of the millers which, of course' cannot be guaranteed in perpetuity (emphasis added). The latter in turn must accept that SAFCOL cannot indefinitely continue to supply them with product at market (sic) prices that are below what a willing and able buyer was prepared to pay.

Evergreen contracts were not endorsed, and ruling prices were acknowledged (apart from the unfortunate use of the adjective 'market') to be below competitive levels.

\section{3}

\section{Long-term contract revision}

Were SAFCOL's attempts to restructure the evergreen contracts justified? There are three arguments in favour and each is refutable. First, government objectives had altered. Second, rewritten contracts were accepted willingly by a majority of millers. And finally, an inequity in the distribution of rights to purchase saw logs was removed. We take these arguments seriatim.

First, SAFCOL's objectives differed from those of DWAF. Plantation forestry was originally encouraged by the State as a consequence of timber shortages arising in two World Wars. Sawmilling did not emerge with sufficient capacity until the late 1940s, and was, in its turn, also encouraged for strategic reasons. A recent paper (Reekie, 2004) describes how long-term contracting and favourable input prices for millers were used as a form of industrial policy from the late 1930s (in the case of prices) and the late 1940s (in the case of security of supply). Government also used the forestry and milling industries to mop up unemployment and alleviate poverty in rural areas. As a commercialised entity SAFCOL was not expected to have such social objectives as corporate goals in and of themselves. Inherited contracts requiring indefinite supply from a forest to an adjacent mill limited its freedom to pursue appropriate silvicultural policies. Planting and felling cycles were contractually rather than economically determined. Choice of miller was indefinitely constrained. Potential entry into milling by the more efficient was thus discouraged, and sale to millers who might have accepted different conditions was precluded. Freedom to engage in contract revision would have enhanced the competitive process.

On the other hand, while government policy has changed, contract law has not. Certainly there is a retrospective regret that contracts were originally written of an evergreen character. But the essence of a voluntary contract is that $e x$ post regrets cannot be predicted ex ante. Contracts can only be adhered to; be written to permit revision in the light of regrets; be revised with mutual consent after the event; or be broken.

Second, the revised terms can be judged appropriate, in as much as they proved acceptable to most sawmillers. SAFCOL renegotiated the contracts with its 16 partners after 1993. Only three customers (accounting for ten per cent of SAFCOL's contractual volume) persistently held out against a renegotiated outcome. The large millers, Mondi, Sappi and Hans Merensky, who purchased 51 per cent of SAFCOL's output by volume, agreed to the revised contracts. The large-scale buyers and the holdouts were offered similar revisions. A presumption is that these revisions provided sufficiently attractive terms to compensate for the loss of evergreen privileges.

Conversely, while large integrated foresters and millers are large customers, they are not totally dependent on SAFCOL for saw logs. Proportionately, the cost of a loss of privilege is to them that much smaller. Contract renegotiation to remove state-granted rights to mill logs is thus a much tougher proposition when dealing with the independents than it is when dealing with integrated mills. This argument is not strong, however. Many smaller independent millers, representing the balance of volume, did accept the revisions. 
The third argument is linked with the first two. There is a market, not of great importance to the integrated forests and millers, but it is crucial for SAFCOL and certainly some independent millers. This is the market for the rents accruing to long-term contract holders. The Chairman of one of the largest independent millers put it as follows:

Why the fuss about our evergreen contracts? Privatisation, that is the reason. Our long-term entitlements complicate the process. Bidders would not place much, if any, value upon a forest subject to a third party's right to harvest indefinitely. The plantations committed to Yorkcor are strategically placed in among the forestry packages being marketed. Shareholders would hardly expect [us] to give those rights away.

... There is no principle of law ... which requires one to give up commercial entitlements without just and equitable compensation ... But collecting compensation is not our business. We are in business to beneficiate wood and make money (emphasis added).

(Yorkcor, Annual Report, 2000: 10).

Full compensation requires that the miller is no worse off after renegotiation. In the market for rents it can be argued that it is not in the public interest that certain private companies should reap their benefits in perpetuity (after all they were awarded in the first instance several decades ago to achieve strategic ends which have long since been accomplished). Rather they should be transferred back to a government vehicle (SAFCOL) that can, in its turn, be sold off. The realisation value of the rights then reverts to the seller (government) and the forestry and saw-milling industries can resume normal commercial relationships.

The difficulty here is that the party in breach is government. At the end of the day, government - or at least a government-owned firm - has enormous litigious power. In some legal systems this is called 'eminent domain'. Why should an independent miller forgo the legal privileges which government voluntarily undertook to award it, embodied in an evergreen contract?
Fischel's (1998: 34-42) discusses the answers normally given to justify an exercise of eminent domain. These are: first, if others have already agreed to deal, any holdout is acting selfishly; and second, it is in the national or public interest. But all that can be said about an independent sawmiller who refuses to accept a rewritten contract on the same terms as others is that he values his original rights more highly than did those who have already traded them in. Of course, the national interest part of the eminent domain argument can then be employed. If others accept given terms, then surely the community is worse off if government accedes to awarding higher compensation to a holdout? That, of course ignores the fact that the holdout is also a member of the community. If an individual firm is forced to forgo its minimum valuation of its rights, the community as a whole is neither better nor worse off than if appropriate compensation had been paid. There remains an efficiency concern within the national interest argument. Evergreen contracts hamper the ability of entrepreneurs to adapt to or to initiate change. Government erred. We would all be better off as members of a dynamic economy if the holdout could be convinced or forced to forfeit his historically acquired rights. But to follow that argument could impose other costs: namely, damaging the integrity of the general contractual and institutional framework.

\section{4}

\section{The Competition Tribunal investigation, 2001}

Yorkcor also complained to the Competition Tribunal. SAFCOL was charged with abusing its dominant market position by a refusal to supply. Specifically it was alleged that a contractually guaranteed volume of saw logs from a particular plantation to a particular mill was not being provided. This put the complainant's business at risk.

SAFCOL's defence was that it was not refusing to supply, but merely reducing guaranteed volumes. In meeting agreed volumes in the past it had been forced into a situation of harvesting 
at a level above the plantation's sustainable yield. It was, however, prepared to make up the deficit from other, more distant plantations (which would increase the cost to the sawmiller) or by accepting bids on the spot market.

The Tribunal decided, as had the Board before it, that SAFCOL was a dominant firm in the relevant market. In this examination the Tribunal, unlike the Board, which examined the national market, restricted its market definition to Mpumalanga. But like the Board, it argued that the area of softwood sawlog production controlled by the integrated firms should not be included. Mondi and Sappi owned approximately 70000 of the total area of 189004 hectares. SAFCOL owned over 70 per cent of the balance (Case 15/IR/Feb 01: 16, n23). The Tribunal argued (para 78) that only in the very long run would these foresters be likely to divert their supplies away from their own mills if offered a high enough price. With this market definition and prediction of conduct charges of abuse of dominance by SAFCOL in the execution or renegotiation of contracts could not be rebutted by reference to the reaction of integrated foresters. This, of course explicitly assumes that the market is defined by the crosselasticity of supply. And, as here, when a charge of refusal to supply is made, that may well be appropriate.

Per contra it is legitimate also to define a market from the side of demand. The Tribunal argued that integrated firms would not be willing to switch supplies to other users except in the long run, and hence they should be excluded from the market (on the explicit premise that the short run would not involve a closure of their milling capacity). But integrated firms can very readily (subject to contract) redirect their pattern of demand. Indeed it could be argued that integrated firms have more flexibility in their choice of supply than do specialist sawmillers. After all, if SAFCOL's log prices to them are set unattractively high, they have their own forests upon which they can draw, while if the external log prices are sufficiently low, it is easy to reduce their own felling rate and redirect demand towards outside suppliers. When defined by cross-elasticity of demand the market in saw logs should thus embrace the integrated as well as the specialist millers. Clearly, from this stance, SAFCOL's market share would then be much less. (Strangely, neither the Tribunal nor the Board examined the saw log market from this aspect.)

The Tribunal, having excluded the integrated millers in its supply side market definition then proceeded in para 79 to conclude that there is potential for abuse of dominance: 'SAFCOL's customer (sic) are unable to substitute ... and, accordingly, SAFCOL is possessed of the power to behave independently of its customers.' But this is internally inconsistent. The relevant market was defined explicitly using the concept of supply cross-elasticity. But the selected indicator of market power, the degree to which SAFCOL's customers could substitute, should then have been measured by demand, not by supply, cross-elasticity. It is the former that provides the appropriate definition of the market when charges of abuse are laid which relate to pricing policy.

It is, of course, abuse with which the authorities are concerned, not dominance per se. But more importantly (absent price discrimination and supply refusal) SAFCOL's clients have considerable discretion (at the time of price revision) to switch custom if they perceive asking price levels are, in their eyes, 'too high'. It is somewhat ironic, therefore, that the Tribunal dismissed the complaint of refusal to supply on the grounds that the dispute 'between the parties ... is, in reality, about price' (para 88).

The Tribunal argued (para 90) that refusal to supply and hence forgo profits is generally unlikely, and that, in particular, neither in the upstream sawlog market (as defined) nor in the downstream sawn timber market was SAFCOL in this instance extending, preserving, creating or threatening to create new sites of market power (paras 93-9):

[Rather it is the] "evergreen" nature of the York contract [which] is offensive to SAFCOL ... because it has enabled York to continue receiving a log supply while simultaneously resisting upward adjustment in ... price ... after years of protracted litigation [and arbitration] ... Should York be prepared to accept terms 
similar to those of SAFCOL's other customers ... then it is difficult to identify the advantage that would accrue ... from withholding supply ... even if York were to exit the market (para 89).

So the Competition authorities (whether operating under the 1979 or the 1997 legislation) have adopted positions that are rather more sympathetic towards unilateral contract revision than might the Courts. This emphasis is probably because the two Competition Acts are, by their very natures, concerned with price determination. Neither Act, implicitly or explicitly, has anything to say about terminating an evergreen contract. That is the business of the civil courts.

\section{5}

\section{Price in the long-term contracts for saw logs}

But why have the saw log prices within the longterm contracts been so contentious? Briefly: to recap, prices were first held below market levels prior to World War II in order to encourage growth of saw milling. Secondly, in later years, a formula was employed based on the landed price of sawn lumber, less average mill costs, including a guaranteed rate of return on capital, and the resulting residual was the log price. The incentives were perverse. The less efficient the sawmilling industry, the lower was its log input price. Its profits were a given.

In 1984 the formula was abandoned. Thereafter, the Forestry Branch of the Department of Environment Affairs had to be financially selfsupporting. Other, non-integrated, foresters who did not have their own milling capacity (and who had little alternative but to accept the government price list) hoped that saw log prices would adjust upwards thereafter (Bremner, 1989: 81). This did not happen.

The inflation-adjusted input prices charged by government forests to sawmillers buying on long-term contract fell by over one-third between 1964 and 1988 (Bremner, 1989: 83). The abandonment of the formula did not affect this trend. Moreover, the prices to foresters for other species, such as eucalyptus, not subject to long-term contracts tended to rise in both real and relative terms over the $1980 \mathrm{~s}$.

The signal of low administered prices had several consequences for the industry's structure. Many growers (Bremner, 1989: 801) 'who were traditionally pine saw $\log$ producers ... switch[ed] to gum'. Pine foresters exited the industry because of low prices. To ensure supplies '[l]arge saw milling companies ... bought scores of farms from timber growers in the northern Transvaal', while at the other end of the scale, because input prices were so low, 'a multitude of new, small, sawmilling enterprises' entered the industry. The continuing real fall in contractual prices set by government resulted in an increasing gap between them and unregulated spot market prices. As an example (Bremner, 1989: 80), the administered price for Grade A logs in 1989 was R14.91 per cubic metre, while the spot price ranged from R32 to R50 per cubic metre.

SAFCOL has continually claimed that it has the aim of raising inherited administered prices to market related levels. Did its behaviour in the 1990s coincide with this assertion? The three sawmillers who held out against the revision of the evergreen contracts were also the principal objectors to the price revisions that SAFCOL attempted to negotiate in that decade. Their argument was that SAFCOL was not only a dominant firm but that it was in many cases the only realistic source of supply for their mills. It could use and was using that dominance to exact a price that, in more competitive circumstances, would be substantially lower.

SAFCOL's defence was rehearsed in the Tribunal Report (paras 71-81). It included some of the following arguments: $(i)$ prices in the long-term contracts were set and revised on a regular basis and were uniform across customers; (ii) revisions had been routine and had been accepted by all (but the holdout) longterm contract holders since 1994; (iii) those willing to accept the price revisions included two of the largest customers, Sappi and Mondi, who were also partially integrated forest and milling firms; (iv) the prices set were the outcome of industry-wide negotiation and information exchange; $(v)$ the prices were nationwide in application and tended not to 
vary with buyer or site-specific costs; (vi) other large-scale foresters such as DWAF (before its assets were acquired) Mondi, Sappi and smaller private growers used the SAFCOL price as a 'benchmark' for determining their own selling price levels, and (vii) SAFCOL charged its own milling subsidiaries the price it negotiated with its other customers.

The Tribunal was unconvinced. In para 79 it noted that long-term contract prices precluded pricing freedom during the life of the contract but that ' $[\mathrm{m}]$ arket power is exercised at the time of the conclusion of the contract'. And furthermore 'the fact that the price is the outcome of negotiation or arbitration does not determine whether or not market power exists.' And again, as already discussed, the Tribunal (mistakenly) defined the market according to supply, not demand, side cross-elasticity. It therefore denied the claim that the presence of the integrated foresters should be regarded as supply substitutes. Having excluded the integrated firms as alternative saw log suppliers from the relevant market the Tribunal was then confined by its own logic. The integrated firms were 'defined out' and their influence on price as buyers was ignored. Participants in the market thus had few if any alternative sources of supply. In para 79 the Tribunal concluded that SAFCOL at the time of price revision 'is possessed of the power to behave independently of its customers [and] simply because it is unable to lay down any price that it chooses [because, for example, of the presence of negotiation, does not mean] it does not possess market power'.

Were SAFCOL's prices during the 1990s 'excessive'? A rational monopolist will never charge a price higher than that at which profits are maximised, nor will the members of a collusive oligopoly, whose aim is to act as if they were a monopoly. A monopoly price in itself need not be excessive, but in general it is the upper bound that will be set in a rational world. Conversely the competitive price is the lower bound, or industry exit will occur. Irrationally low (regulated and effectively subsidised) levels typified the situation prior to the formation of SAFCOL.
The problem with the arguments put forward by SAFCOL to the Tribunal is that they were consistent with each of the theories of perfect competition, monopoly, and for that matter, collusion. Absent price discrimination uniform prices (see $i$ above) across customers can be expected whether market power is present or absent. Routine price revisions (ii) to adjust to shifts in costs or demand conditions are a characteristic of both monopoly and competition. Similarly information exchange and negotiation (iv) could be seen either as surrogates for the Walrasian auctioneer of perfect competition, or the necessary prerequisite for a monopolist seeking to ascertain just where his demand schedule lies. Uniform prices across buyers and regions ( $v)$ can indicate competitive behaviour, but if the supplier's marginal costs vary across such market segments they can also indicate the presence of price discrimination.

These arguments are necessary but not sufficient conditions for inferring the presence of a competitive price structure. Even more inconveniently, they are ambiguous. There remain arguments (iii), (vi) and (vii). Argument (iii), that if the market is properly defined to include buyers who can switch their source of supply then a seller cannot act independently, has already been discussed. This is not theoretically ambiguous and hence reinforces the competitive rather than the monopolistic interpretations of the four necessary conditions. The other arguments relate to the concepts of barometric price leadership on the one hand, and transfer pricing and bilateral monopoly on the other.

Argument ( $v i)$ is that the others in the industry, both small growers and the large foresters, use the SAFCOL price as a 'benchmark' when setting their own selling prices. The word 'barometric' is more often used in this context in economic literature (Markham, 1951). Barometric pricing occurs when others follow the initiator of an adjustment. They will do so only if they believe the leader has a sound understanding of the market dynamics, whether on the supply side and related to underlying costs, or on the demand side and related to consumer 
requirements. Barometric leadership is a mechanism for arriving at market-determined prices. Such a firm is 'the eyes and ears' of the industry (Monopolies Commission, 1973: 12). Its behaviour reflects market conditions. The firm may err, but it will lose its leadership role. If it persistently holds the role the likelihood of its making a misjudgement can be deemed to be low, on the evidence of the behaviour of other market participants, whether buyers or sellers. Otherwise they would have disregarded the leader.

Barometric pricing differs from both collusive and dominant firm leadership. The latter is an inappropriate theory for explaining the facts in this industry (Worcester, 1957). For it to be applicable we would have expected to see SAFCOL cutting prices to force 'fringe' firms to merge to achieve any scale economies the price leader possessed. Neither part of that scenario (price cuts or fringe firms merging) has been in evidence. Collusive leadership, with foresters behaving as if they were a monopoly, is also not borne out by the facts. (Neither the Board nor the Tribunal suggested prices were at excessive levels; the Board indeed specifically stated prices could not continue to persist below levels which willing buyers and sellers would agree to.) Furthermore, in its transfer price behaviour (see infra), SAFCOL acts as if its price was indeed a market (ie a barometric) price, not a collusive price. To summarise, the discussion to this point reinforces the competitive, not the monopolistic, interpretation of price setting in forestry.

What of argument (vii), the transfer price behaviour of SAFCOL? This is linked to the difficult issue of bilateral monopoly. Bilateral monopoly could appear to be of significance. If the geographic market is defined sufficiently narrowly, one forester sells all, or a large proportion of his logs to a single sawmiller, and vice versa. And indeed most long-term contracts do indeed relate to a particular plantation and an identified adjacent sawmill. Stigler (1966: 207-8) pointed out that the objectives of buyer and seller are then 'inconsistent' and price and quantity 'indeterminate'. This says Stigler, is merely a 'refined way of saying that it is not fully understood'. Any observed quantity or price 'will have been determined by factors outside [microeconomic] theory [such as] skill in negotiation'. The situation is not without hope, however. Stigler goes on to indicate that there is a unique, theoretically determinate point where the 'total profits of the two firms combined would be larger at [that] point than any other'.

In other words while we cannot explain why a given price is arrived at in a bilateral monopoly, we can, at least in principle, say what the price should be to maximise joint and several profits. The normative principle is that of transfer price theory, given the hypothetical assumption that the buyer and seller are vertically integrated. Hirshleifer (1956) stated that either of the following considerations should apply: (a) if there is an open external market transfer price principles dictate that the market price be charged; (b) if no open external market exists, pure bilateral monopoly, transfer price principles require that the price be set where the seller's marginal cost equals the purchaser's net marginal revenue.

There is an open external market. Saw logs can be sold throughout the country, and for that matter internationally. So to rephrase the argument, even in an exclusive trading situation such as a long-term saw log contract, if an outside market exists, the price charged, to be mutually beneficial and to result in joint wealth maximisation, will be the same as that ruling in the outside market. SAFCOL's forest division sells to its own sawmills at the same price as it sells to all outside customers. This argument therefore also supports the overall thesis that SAFCOL's pricing behaviour is competitive rather than determined by the presence of market power.

\section{6}

\section{The strategic pricing debate}

The largest holdout sawmiller, Yorkcor, disagreed with this analysis on at least two fronts. First, it hinted that there might be evidence of tacit collusion between SAFCOL and Mondi in the setting of price. And second, it stated that it believed it was the victim of such collusion 
between the large integrated groups as a consequence of predatory pricing behaviour.

The Tribunal (2001: para 88) noted that if a miller held out against a price revision it could defer paying a price increase for 'years'. Protracted litigation could and did achieve that end. In the interim all other buyers and sellers of saw logs would be paying and receiving ruling market rates. Because of this, in 1999 Mondi complained to the Competition Commission that SAFCOL was practising discriminatory pricing by favouring Yorkcor with lower buying prices than it was charging to its other customers, including Mondi. This could be interpreted as the natural annoyance of a rival over the commercial advantage gained by an isolated holdout. Or it could be viewed as tacit collusion between SAFCOL and Mondi, both integrated firms, to force a mutually agreed saw log price on an unwilling purchaser. Yorkcor's interpretation can be inferred from its 2000 Annual Report. The company's Chairman wrote: 'One wonders what motivates Mondi to lodge (this) complaint ... One can but speculate what is cooking below the surface.'

Yorkcor was more explicit about its other concerns over predatory behaviour by SAFCOL and the integrated foresters. In its Chairman's Statement in the 1996 Annual Report it was noted that:

[p]redatory pricing by the majors (of sawn timber) was rife ... Six long established sawmills have gone out of business.

Moreover, the

squeeze on sawmillers' margins was at both ends ... the hike in $\log$ prices was tantamount ... to a predatory raid ... [although] the ostensible justification [for the rise] was the drive towards so-called international parity for $\log$ prices.

But this argument ignores the weight of economic literature which assumes that predatory behaviour is just too costly to use against rational competitors. McGee (1988: 223-4) discusses that literature and concludes that rational firms are unlikely to try for or to achieve monopoly power via predation. Where it has been successful it can be explained on grounds of either irrationality or error, neither of which is the stuff of useful economic theory (McGee: 221). What is the situation here?

The mechanics of the alleged strategic 'squeeze' were apparently to drive log prices up towards export levels while simultaneously selling sawn lumber at very low prices. Independent millers, therefore, were 'squeezed' by artificially high input prices, and had to hold their output prices artificially low to meet the lumber price of the integrated foresters. This implies that SAFCOL was practising collusive rather than barometric price leadership. Given that other buyers accept the SAFCOL asking price for logs, one has to ask what the integrated firms have to gain by doing so if their aim is predation, and how they can realise that gain? Two possible explanations suggest themselves. First, other log buyers cannot afford to enter into costly litigation to the extent that Yorkcor has done. These other buyers include international companies with 'deep-pockets' so this is unlikely. Second, the integrated firms have other sources of saw logs and have an interest in increasing the SAFCOL price to those of their competitors for whom SAFCOL logs represent a larger proportion of total log input.

The accused predators are then presumably forfeiting profits today in the hope of reaping greater profits tomorrow. Tomorrow's profits depend on millers without their own log supplies being driven out of business by lower priced sawn lumber produced by the mills with the cheaper saw log input mix, at which point the guilty integrated millers will raise their lumber prices and start to earn a return on investment in their strategy. For a range of reasons this is implausible. Of SAFCOL's three main customers, only Mondi is a big grower, while Merensky obtains all its logs on the market place, having no plantation resources. The argument therefore relies on collusive 'squeezing' by only the former two firms. The latter firm, and the other specialist millers, have accepted the barometric role of SAFCOL without allegations of a 'squeeze'.

Second, the charge of predation implies nonprofit-maximising behaviour by the foresters/ millers in question for as long as they transfer logs internally at below the outside market price. This behaviour, in turn, must continue long 
enough for victim firms to be weakened before the predators can raise their lumber prices. A long time would have to elapse. Losses would be incurred not only on the original low-priced log or lumber volume, but also on the increased volumes generated by the artificially low prices.

Third, to reap the pay-off from the predatory investment the predators would have to increase their lumber prices to a high enough level and for a long enough time to make the investment worthwhile. But higher-than-market prices for a prolonged period in the future might well put paid to such strategic goals. Market entry, expansion of other mills, and increased imports of lumber would become likely just as the predators hope to gain their rewards.

Finally the strategy, if present, would require continuous collusive behaviour by the integrated millers to forego current profits. The likelihood of 'chiselling' on the alleged agreement, by selling sawlogs below any claimed cartel price but above the alleged artificially low internal transfer price would have been high. So too would have been the temptation to raise lumber prices whenever a shortage appeared in the hope of 'free-riding' on the predation strategy.

But the statement cited above had two parts. The second charge related more specifically to SAFCOL as price setter. Saw millers allegedly exited the industry because input prices were too high in relation to those of sawn lumber. SAFCOL could then be accused of operating irrationally with too short a time horizon, and of pricing irrationally at high levels to maximise short-term gains. Or it could be accused of raising prices to what the market will pay (the example given was the export market) but in doing so deliberately achieving price levels that were uneconomic for its unwanted long-term contract holders.

But we already know that saw log prices in South Africa had been held at administered (and low) levels for several decades. It is not surprising, therefore, that foresters switched from pine and sawmillers moved into the industry in these years, nor that these trends would be reversed when prices were freed from administrative control. What is less clear is whether resistance to this reversal is merely about price, or whether it is about the more fundamental issue of contractual integrity where pricing disagreements are symptoms of a deeper malaise.

Section 7 relooks at the problem of price from the particular perspective of the evergreen contracts. Was the main dissenting sawmiller practising opportunistic hold-up in a bilateral monopoly situation? Or is the explanation of holdout against an exercise of eminent domain more plausible?

\section{7}

\section{Bilateral monopoly and opportunistic hold-up}

The long-term contracts obliged supply of a minimum specified quantity of sawlogs from a particular plantation to a particular mill. The sawmiller tended to have the right of first refusal to any excess and agreed not to sell on unmilled logs to third parties. The contracts therefore provided symbiotic relationships between both parties, akin to those of bilateral monopoly. There are asset- and site-specific aspects to the traded good logs. Sawmills, once built, and forests, once planted, are not fungible. Neither party has available alternative market outlets or supply sources at no cost. When both parties agree ex ante to supply and be supplied, there is the inevitable danger that ex post moral hazard or hold-up will occur. That is, one party may opportunistically attempt to renegotiate prices in its own favour after the date of the contract, different from those fully informed contractors would have negotiated at the date of agreement. Other things equal, transaction cost economics suggest that where asset specificity and opportunism are both present, vertical integration or long-term contracting helps attenuate transaction costs by reducing the hazards of opportunism (e.g. hold-up). Williamson (1985, Ch. 1) notes that asset specificity reduces the likelihood of impersonal market exchanges. Traders are not indifferent as to who the partners are and with whom they deal. While the presence of moral hazard and opportunism raises the costs of court-based contractual enforcement. Infrequently negotiated but highly specified contracts, or 
vertical integration, are then less costly trading alternatives than either impersonal market exchanges or spot- or short-term contractual deals founded on the principles of dictum meum pactum and moderated only by laws of tort or delict.

Long-term deals are a trading mode designed to attenuate hold-up problems. But even longterm contracts are subject to opportunistic holdup at the time of contract revision. In this particular case the contractual constraints on the forester at the time of revision are greater than those on the miller (he cannot terminate nor cease supplying; the miller can continue to pay the old price). The cost of opportunism is lower for the latter. Unsurprisingly it is the sawmillers who have practised hold-up during price negotiations.

Of course, an infinitely long contract with no provision for revision of any sort could imply unitary ownership and full vertical integration. The hold-up problem would vanish, although other costs would then be incurred relating to the co-ordination and control of a more complex firm. In the absence of unitary ownership the hold-up problem could also disappear, provided the other party's future behaviour, at the date of contract writing, was constrained. To avoid hold-up, this would require no walk-away rights. But in this case government did award partial walk-away rights to the sawmillers (they could continue paying the old price, while supply could not be terminated). Through its subsequently formed corporate entity, SAFCOL, government is now experiencing post-contractual regret owing to the presence of opportunistic hold-up hampering market-related price adjustments.

Nevertheless, there is more to it. Contractually agreed price renegotiation provisions compensate for all changes which were unanticipated by both parties and which, had they been known ex ante, would have resulted in different contractual terms. But if other institutional or environmental changes occur which have no effect on price and which are unprovided for in the contract, then economics is silent. If such changes occur and result in windfall gains or losses to one party without impacting on the wealth of the other, then one party may feel aggrieved. It may believe, retrospectively, that it erred in contract construction, but in the absence of breach with compensation, economics has little to say. SAFCOL, as it attempted to rewrite the evergreen contracts prior to privatisation, was simply attempting to recapture the windfall gains that the somewhat peculiar rights of the long-term contracts had awarded the sawmillers. The millers then practised opportunistic hold-up, certainly, but not to 'exploit' asset specificity in bilateral monopoly. They were after all being asked for the joint and several profit-maximising price for saw logs, a price they would levy on themselves if they owned their own plantations, namely the market price. Rather they were practising hold-up to reinforce their holdout as they defended contractually-awarded, wind-fall property rights in the face of SAFCOL's attempted exercise of eminent domain.

\section{An auction as a solution?}

Government has been attempting to privatise and restructure its forestry assets by selling off various regional packages to different bidders. The process has been slowed by the presence of historic, 'evergreen' contracts between independent sawmillers and the state company, SAFCOL. Over a decade some sawmillers have practised opportunistic hold-up in refusing to accept and pay the price for saw logs asked for by the state forester. That price can be regarded as a market-determined price. It is not the consequence of undue use of bargaining power by the state company in a situation of bilateral monopoly, which in any event is more apparent than real. Rather, some sawmillers are protesting against a more general revision of their contractual entitlements. The attempted rewriting of contracts by the state company is in essence an exercise of eminent domain. The sawmillers are holding-out against this process.

To "nudge" the industry to a more competitive situation, government must buy out these interests. The difficulty is to arrange a situation where the incumbent miller (Y) will reveal his 
desired compensation level for giving up the right to be supplied with logs in perpetuity. Privatisation of the forests provides an opportunity for government to discover the figure competitively, while the means of discovery can be built into the privatisation process itself.

Consider the workings of a simultaneous ascending auction (SAA) as described by Milgrom (2000). SAFCOL's forests could be sold to $\mathrm{Y}$, or to any other outside buyer, $\mathrm{X}$. Bids from $X$ would not be deterred by the presence of still unknown compensation levels for Y. In an SAA items for sale are offered simultaneously, and the auction concludes for any individual item only when it concludes for all. In this case there are two items offered for 'sale': first, the obligation to supply trees to Y in perpetuity, and second, the standing trees themselves. ${ }^{2}$

The successful bidder for item 1 would be the one who is willing to accept the lowest price from government to assume the obligations of the evergreen contracts. The successful bidder for item 2 would be the one who offered the highest price for the forests. The two items are offered simultaneously. The auction would not conclude for any one item until it concluded for both. In each of a sequence of rounds, bidders may submit new bids for one or both items. (An activity rule precludes withdrawal of bids for the respective items if a new bid is made for the other.) After each round, the results of the bidding are publicised and the identities of the lowest bidder (for item 1) and the highest bidder (for item 2) are publicised. The auction would continue until no new bids were submitted and the respective winners would receive their items.

If $\mathrm{Y}$ wins item 1, the problem is over. Compensation for abolishing the evergreen contract has effectively been paid. Y or X could win item 2. (Since $X$ would now be supplying $Y$ the obligation on $\mathrm{Y}$ to supply himself becomes meaningless.)

If X wins item 1 (and knows Y's negative bid) he can bid for the standing trees in the knowledge of Y's compensation requirement which is higher than X's, but is capped, by virtue of the auction process, to avoid its being exploited opportunistically. If X wins item 2 he would wish to rewrite the contracts without the evergreen component, but he knows the level of compensation $Y$ would require for breach. If $Y$ wins item 2 he now owns the trees but does not have the legal obligation to supply himself ( $\mathrm{X}$ has that obligation). $\mathrm{X}$ could now be subject to opportunistic behaviour by Y, who might for example harvest trees at some non-viable rate, and, when supplies are exhausted, ask X to find trees for the mill. Aware of this, $\mathrm{X}$ would attempt to get out of the obligation immediately by paying off $\mathrm{Y}$ with the cash $\mathrm{X}$ had received when winning item 1.

There remains one problem. Why should $\mathrm{Y}$ participate in the auction at all? Y may consider that pursuing compensation through the courts is more attractive. In order to ensure Y's participation a "floor" price (negative) must be predetermined as an activity rule, sufficiently high to attract $Y$ into the process, but sufficiently low (as a negative figure) for the initial negative price offers to government to be pitched well above that floor in the auction process.

This solution is not perfect. But when contracts have been written legally by government to provide windfall gains to one partner at the expense of another, then an SAA is perhaps the only economic or market-based way of moving away form an inherently uncompetitive situation.

\section{9 \\ Summary and conclusions}

This paper has drawn on transaction cost analysis, price and auction theory, and competition authority findings in order to answer some questions on the structure and trading patterns of the South African forestry industry.

Does a forestry firm linked contractually to supply an adjacent sawmill customer form part of a bilateral monopoly? For competition policy what are the relevant markets each party sells into or buys from? Can either firm opportunistically hold-up the other in price revisions? Or, where contracts have no effective terminal date, can one party hold out against 
offers of contract buyout? If one party is a state agency are there rights of eminent domain? Can these be exercised in the public interest? If the state agency is due to be privatised the method of sale, for example a simultaneous ascending auction, can help resolve some of the dilemmas.

\section{Endnotes}

1 The author thanks two anonymous referees, Robert Kruse, Somdeb Lahiri and S du Plessis for criticisms on earlier drafts. The usual disclaimers apply.

2 This separation of the two items into individual competitive bids for the "obligation to supply" and for standing trees respectively is not novel. It is conceptually similar to the dichotomy defined by Demsetz (1968) when he noted that competition can be for the market and not in the market. The "business" being sold by government includes the contractual obligations. There can be competition for that business, although after the auction these will not be competition in that business. There will be operations only in the field of selling trees, subject to the already existing rivalries in the forestry product and capital markets, unencumbered by evergreen obligations.

\section{References}

1 BREMNER, J.M. (1989) "Softwood sawlog prices: A private grower's statement”, South African Forestry Journal, 151(December): 80-9.

2 COMPETITION BOARD (1998) Investigation into the South African Forestry Company Ltd, Report No. 61: Pretoria.

3 COMPETITION TRIBUNAL (2001) York Timbers vs SA Forestry Company Ltd, Case No15/IR/Feb01.

4 DEMSETZ, H. (1968) "Why regulate utilities?" Journal of Law and Economics, 11.

5 FISCHEL, W.A. (1998) "Eminent domain and trust compensation" in P. Newman (ed.) The New Palgrave Dictionary of Economics and the Law, vol 2, Macmillan: London.

6 HIRSHLEIFER, J. (1956) "On the economics of transfer pricing", Journal of Business, 29.

7 MARKHAM, J.W. (1951) "The nature and significance of price leadership", American Economic Review, 41.

8 McGEE, J.S. (1988) Industrial Organisation, Prentice Hall: Englewood Cliffs.

9 MILGROM, P. (2000) "Putting auction theory to work: The simultaneous ascending auction", Journal of Political Economy, 108.

11 MONOPOLIES COMMISSION (1973) Parallel Pricing, Cmnd 5330, HMSO, London.

12 REEKIE, W.D. (2004) "The wood from the trees: Ex Libri ad historiam pertinentes cognoscere", South African Journal of Economic History.

13 STIGLER, G.J. (1966) The Theory of Price (3 $3^{\text {rd }}$ ed.) Macmillan: New York.

14 WILliAMSON, O.E. (1985) The Economic Institutions of Capitalism, Collier Macmillan: London.

15 WORCESTER, D.A. (1957) "Why 'dominant firms' decline”, Journal of Political Economy, 65. 